\title{
RECEPTION OF THE INSTITUTES OF THE CONSTITUTIONAL MECHANISM FOR THE PROTECTION OF HUMAN RIGHTS IN UKRAINE
}

\author{
Verlos N. V.
}

\section{INTRODUCTION}

The current stage of state building in Ukraine is characterized by qualitative changes in the institutional design of the constitutional mechanism of public power where the human rights institutions take the leading place. The process of constitutional and legal modernization in the context of the tendencies of global constitutionalism is accompanied by the reception of ideas, doctrines, concepts and institutions focused on building a democratic organization of the society, ensuring the rule of law, recognition of human rights and freedoms as the highest social value, and optimizing the mechanism of guarantee and protection of human rights and freedoms.

Constitutional-legal modernization is in fact a combination of qualitative changes of the legal system, and this process is therefore impossible without the use of the international experience and the reception of positive achievements of the advanced democracies.

The problem of the reception has become especially relevant in the context of Ukraine's foreign policy towards European integration, which in its turn requires to harmonize, the national legislation of Ukraine with that of the European Union. Thus, in 2014, Ukraine ratified the Association Agreement with the European Union ${ }^{1}$ and finally embarked on the path of European integration and, as stated in the Parliament's statement, «the Verkhovna Rada of Ukraine considers ratification of the Association Agreement between Ukraine and the European Union not only as a stimulating factor for further reforms in Ukraine, but also as a further step on the way to achieving the ultimate goal of European integration gaining full membership in the European Union» ${ }^{2}$. In addition, in

\footnotetext{
${ }^{1}$ Про ратифікацію Угоди про асоціацію між Україною, з однієї сторони, та Європейським Союзом, Європейським співтовариством $з$ атомної енергії і їхніми державами-членами, з іншої сторони: Закон України від 16 вересня 2014 року URL: http://zakon2.rada.gov.ua/laws/show/ 1678-18.

2 Про Заяву Верховної Ради України «Про європейський вибір України»: Постанова Верховної ради України від 16.09.2014 p. URL: http://zakon5.rada.gov.ua/laws/show/ru/1679-18.
} 
accordance with the constitutional changes of 2019, the preamble to the Basic Law proclaims the «irreversibility of the European and EuroAtlantic course of Ukraine» ${ }^{3}$.

As one of the vectors of constitutional and legal reform in the context of the European integration is the improvement of the system of guaranteeing and effectiveness of the constitutional mechanism of human rights protection in Ukraine. This process should be carried out including qualitative updating of existing and the reception of the ways of protecting constitutional human and citizen rights. That is why the issue of the possibility and necessity to continue the reception of the ombudsman institute and the mediation institute is highly topical.

\section{Improving the functioning of the institute of ombudsman based on the foreign experience}

The constitutional development of the modern democratic state, determined by the idea of people-centrism, is oriented towards the search for new institutional forms in the field of human rights protection. The legal nature of public authority is the desire to expand the limits of influence on the society, and it is therefore important to develop an effective deterrent mechanism that will contribute to the prevention of the attacks against the human rights as well as violation of them by the public bodies and their representatives.

In the context of reformation, under the influence of the globalization and internationalization of constitutional law, there is the reception of the institutes that have already been tested over time and function effectively in the foreign countries. The institute of ombudsman is one of the sort in the field of human rights protection. In the context of constitutional and legal modernization, the borrowed institute of ombudsman implemented into the legal system of Ukraine receives qualitatively updated characteristics and requires a comprehensive analysis of the specifics of functioning.

In the process of world democratization, most states try to create new and update existing models of human rights institutions. In Ukraine, the evolution of the institute of ombudsman is underway, and therefore the study of the issue of the place and role of this human rights institute in the constitutional mechanism of human rights protection is quite relevant at the present stage of state building.

\footnotetext{
${ }^{3}$ Про внесення змін до Конституції України (щодо стратегічного курсу держави на набуття повноправного членства України в Європейському Союзі та в Організації Північноатлантичного договору: Закон України від 07.02.2019 p. URL: https://zakon.rada.gov.ua/laws/show/ 2680-19\#n6.
} 
The term «ombuds» comes from Scandinavia, in particular in the translation from medieval Swedish the word «umbud» meant «power» and «authority» ${ }^{4}$. The institute of ombudsman was first established in Sweden in the early 19th century.

In the British Encyclopaedia, the term ombudsman is defined as «... an independent public official investigating citizens» complaints against officials and government authorities» ${ }^{5}$. Foreign researcher D. Rowat defines ombudsman as «an independent and impartial functionary of a legislative body, which oversees the activities of state bodies, considers complaints of citizens in connection with administrative arbitrariness and maladministration» ${ }^{6}$.

In constitutional doctrine there is no consensus on the definition of the ombudsman. For example, some scholars .... this status as an official, in particular, P.P. Shlyakhtun defines the ombudsman as «... a specially elected or appointed official to control the observance of human and civil rights by public authorities, first of all, state executive bodies» ${ }^{7}$. V. Barchuk defines ombudsman as «... a senior official, appointed, as a rule, by the parliament, authorized by the Constitution or a separate law to control the observance of human and civil rights and freedoms by public authorities, sometimes by local self-government bodies and their public officials» ${ }^{8}$.

Other scholars define the term as a «state body». Namely K. O. Zakomorna defines the term of ombudsman as «... a highly authoritative, independent, functionally self-directed, politically neutral state body designed to ensure the exercise of human rights and freedoms of that uses in its work the unconventional criteria for assessing violations of human rights and freedoms committed by public authorities, institutions and organizations, and it affects them morally» ${ }^{9}$. Khamaneva N. Yu. proposes to define the ombudsman as «... an independent public body

${ }^{4}$ Howard Ch.L. The Organizational Ombudsman: origins, roles and operations: a legal guide, Chicago: AmericanBar Association, 2010.642 p.

${ }^{5}$ The World Book Encyclopedia. Field Enterprise as Educational Corporation / Holbert N. Corrol. - N.Y., 1972. V. 14. P. 574.

${ }^{6}$ Rowat D. C. The Ombudsman, Citizcnis Defender: Pref'ase to Second Edition.London: George Allen and Unwin, 1986. - S. XXIV.

${ }^{7}$ Шляхтун П.П. Парламентаризм: словник-довідник. К.: Парламентське вид-во, 2003. С. 86.

${ }^{8}$ Барчук В.Б. Уповноважений Верховної Ради України 3 прав людини як суб'єкт забезпечення національної безпеки: автореф. дисертації ... кандидата юридичних наук 12.00.02. K., 2006. C. 10.

9 Закоморна К.О. Інститут омбудсмана як засіб забезпечення прав і свобод людини та громадянина (порівняльно-правовий аналіз):автореф. дисертації ... кандидата юридичних наук: 12.00.02, Харків, 2000. С. 9. 
directly concerned with the protection of the rights and legitimate interests of a person violated by the acts or omissions of administrative bodies and officials» ${ }^{10}$.

There is also a position according to which the term is defined as a «public authority». A.V. Martseliak notes that the ombudsman is «... appointed by the supreme bodies of state power to be a supervisory, human rights, independent, politically neutral, one-person or collegial body of state authority (official), empowered by the constitution or the law on its own initiative or according to the citizen appeal to control official bodies and officials (especially the executive branch) in terms of respect for rights and freedoms of man and citizen, who usually acts informally at its own discretion and recommends corrective actions committed to the proper protection of these rights and freedoms» ${ }^{11}$.

There is an interpretation of ombudsman as a "public-law institute». Thus, L. V. Golyak, proposes to define «the specialized ombudsman institution as an independent, self-directed, public, as a rule - state or public institute, established for the purpose of ensuring the state (or equivalent public) protection of rights and legal the interests of the persons belonging to vulnerable groups of the population and social groups, the observance of the rights and freedom of these groups and respect by public authorities and local self-government bodies, by their officials, as well as organizations, institutions or other institutions, who specialize in providing public services $^{12}$.

The stated positions of the scientists can be partly agreeable with, but we believe that the ombudsman is an organizationally separate, relatively independent and politically neutral state body whose main task is to promote the protection of human rights and citizens from violations made by public authorities or their officials ${ }^{13}$.

The classic model of ombudsman, which may exist individually or collectively, comes from the Swedish ombudsman established in 1809 and other institutes of ombudsman of the Scandinavian countries (in Finland it was founded in 1919; Denmark - in 1955; Norway - in 1962, and Norway

${ }^{10}$ Хаманева Н. Ю. Место и роль института омбудсмана в системе правового контроля. Правоведение. 1992. № 2. С. 84-88.

${ }^{11}$ Марцеляк О.В. Конституційно-правовий статус інституту омбудсмана: світовий досвід та Українська модель: автореф. дисертації ... доктора юридичних наук 12.00.02. Одеса, 2004. С. 8.

${ }^{12}$ Голяк Л.В. Інститут спеціалізованого омбудсмана: світовий досвід організації та діяльності: дисс. ... канд. юрид. наук. спец. 12.00.02, К., 2009. С. 28.

${ }^{13}$ Верлос Н.В. Омбудсман в механізмі захисту прав людини в Україні: пошук ефективної моделі в контексті запозичення зарубіжного досвіду Вісник Запорізького національного університету: Збірник наукових праць. Юридичні науки. 2018. № 2. С. 25. 
in 1962). The idea was distributed worldwide (New Zealand - 1962 and Australia - 1977). The original idea of the classic model of the ombudsman was far from the ideals of human rights. It was simply an institution focused on ensuring the rule of law in public administration ${ }^{14}$.

The institute of ombudsman was widely spread after the Second World War, which was due to a number of reasons: the world community realized that the maintenance of the world order would be impossible without respect for human rights and freedoms, civic activity increases ${ }^{15}$ and the activities of state structures boosted. Also public authorities were given discretionary powers. It caused the necessity to introduce new mechanisms of protection against arbitrariness of the officials ${ }^{16}$. Then the humanity became aware of the need to establish effective and innovative institutes, one of which was the institute of ombudsman.

Today, the legal Institute of ombudsman is operating effectively in the United Kingdom, Switzerland, Portugal, Australia, Spain, Germany, Italy, the Netherlands, Croatia, the Czech Republic, Bosnia and Herzegovina, Macedonia and others. In the post-socialist countries, the institute of ombudsman was established in Ukraine, the Russian Federation, Georgia, Moldova, Uzbekistan, Azerbaijan, Armenia, Kazakhstan, and others.

In the legal literature, three models of the ombudsman distinguished by their nature and place in the state legal system and the procedure for appointing them are specified: 1) the executive ombudsman (quasiombudsman), appointed by government or president (France, USA); 2) the independent ombudsman is an independent branch of power, the level of which corresponds to the level of the legislative, executive and judicial branches. Appointed by the President or Parliament but not subject to the appointing authority (Portugal, Namibia, Netherlands); 3) the parliamentary ombudsman is part of the legislative system, he or she is appointed (elected) by the parliament and is under control of the parliament ${ }^{17}$.

${ }^{14}$ Cheng, HingYong. The Emergence and Spread of the Ombudsman Institution. Annals of the American Academy of Political and Social Science. 1968. Vol. 377. May. P. 20-30.

${ }^{15}$ Rowat D. The Ombudsman Plan: The Worldwide Spread of an Idea. Rev. 2nd ed. Lanham: University Press of America, 1985. P. 131.

${ }^{16}$ Seneviratne M. Ombudsmen 2000 URL: www.bioa.org.uk/BIOANew/Ombudsmen-2000Mary\%20Seneviratne.pdf.

${ }^{17}$ Мухитдинов Е.Н. Институт омбудсмана (упролномоченного по правам человека) в международном праве: история возникновения и развития в странах мира и Казахстана. ҚР ҰҒА баяндамалары=Доклады Национальной академии наук Республики Казахстан. 2008. № 6. С. 104-105; Новикова А.Е. Институт Уполномоченного по правам человека в Российской Федерации (историко-правовой и теоретико-правовой аспекты): автореф. дисс. ... канд. юрид. наук: спец. 12.00.01; 12.00.02, СПб., 2007. С. 8. 
The parliamentary model of the Ombudsman is considered to be a classic one. However, generally agreeing with the proposed classification of Ombudsman models, it should be noted that the practice of operating in foreign countries is mainly indicative of the real existence of a «combined» model, which simultaneously combines several models of the ombudsman with different status ${ }^{18}$.

Based on three basic models, scientists propose to classify ombudsmen and their legal nature and territorial context by dividing them into: 1) an international ombudsman; 2) the European ombudsman (Commissioner) for Human Rights; 3) national ombudsman; 4) the regional ombudsman; 5) the ombudsman acting locally/local ombudsmen ${ }^{19}$.

In the process of the reception of any institute, it can acquire specific features, which can contribute to the formation of a qualitatively updated model. For example, after borrowing the idea of the institute of ombudsman, the US developed and modified it. Unlike other states where the institute of the ombudsman had some difficulties in the implementation process, which were accompanied by overcoming political, social and legal barriers, in the USA the establishment of the institute of ombudsman received active public support, including from the legal community. As early as 1967, the American Bar Association established an Ombudsman committee within the administrative law section and, in 1971, passed a resolution on the need to develop the ombudsman's concept at both federal and state levels ${ }^{20}$.

Because of borrowing from the classic model of the ombudsman and being perceived by the American legal system, it has transformed, differentiated, and therefore an updated model of this human rights institute emerges as a «quasi-ombudsman».

According to the American researchers, the concept of «quasiombudsman» includes all derivatives of the classic model of the Ombudsman, and its peculiarity is that this institute has spread not only in the field of public-legal relations, but also in the sphere of private legal regulation. For example, the idea of the Institute of Organizational or Corporate Ombudsman, which is a structural unit of an institution/

\footnotetext{
${ }^{18}$ Верлос Н.В. Омбудсман в механізмі захисту прав людини в Україні: пошук ефективної моделі в контексті запозичення зарубіжного досвіду Вісник Запорізького національного університету: Збірник наукових праць. Юридичні науки. 2018. № 2. С. 26.

${ }^{19}$ Новикова А.Е. Институт Уполномоченного по правам человека в Российской Федерации (историко-правовой и теоретико-правовой аспекты): автореф. дисс. ... канд. юрид. наук: спец. 12.00.01; 12.00.02, 2007. С. 8-9.

${ }^{20}$ Носырева Е. И. Особенности института омбудсмена в США. Право и политика. 2001. № 9. C. 12-15.
} 
corporation created to resolve conflicts within that organization, in particular between employer and employee, between management personnel and subordinates, has recently been distributed. It was established in such corporations such as IBM, AT\&T, Bank of America, Washington Post ${ }^{21}$, and many universities (university or student ombudsmen) ${ }^{22}$.

However, some American researchers, including J. Lubbers, have stressed the controversy of using the term «ombudsman» to specify existing alternative human rights institutions. In particular, the researcher points out that, in general, the foreign origin of this term is meaningless to most people, but in the United States «... four states, twenty federal agencies and more than 1,000 corporations set up ombudsman offices, using alternative names such as «lawyer», «representative of the citizen» and «mediator» ${ }^{23}$. That is, the borrowed model of the ombudsman in the United States over time lost its identity and ceased to perform the functions that characterize the classic model of the ombudsman. The US experience should be taken into account in the process of adopting a borrowed model of the ombudsman in Ukraine.

Today, the effectiveness of the institute of ombudsman depends on a number of factors, including the development of scientific and technological progress. Namely, as M. Seneviratne notes, the emergence of modern electronic communications technologies, in particular the Internet and personal computer, has great potential for strengthening democratic power ${ }^{24}$. This potential is particularly evident af fot the institute of the ombudsman, which plays an important mediating role in addressing public complaints against members of the public administration. But to what extent will this potential be realized? Of course, the current offices of the ombudsman should take advantage of state-of-the-art electronic technologies to better communicate with the public and improve the quality of service given to the public ${ }^{25}$. In his

${ }^{21}$ Спичак Ю.Г. Модели института омбудсмана на современном этапе. Государственное строительство и право. 2003. Вып. 4. С. 53-62.

22 Janzen Fred G. A historical study of the campus ombudsman Inunited states higher education: a dissertation Ineducation Submitted to the Graduate Faculty of Texas Tech University in Partial Fulfillment of the Requirements for the Degree of doctor of education, Texas 1971. $254 \mathrm{p}$.

${ }^{23}$ Lubbers Jeffrey S. Ombudsman Offices in the Federal Government - An Emerging Trend Administrative Law and Regulatory Practice. Spring 1998 Volume 2. № 1 URL: https://www.americanbar.org/newsletter/publications/gp_solo_magazine_home/gp_solo_magazine_ index/lubbers.html.

${ }^{24}$ Seneviratne M. Ombudsmen 2000 URL: www.bioa.org.uk/BIOANew/Ombudsmen-2000Mary\%20Seneviratne.pdf.

${ }^{25}$ Hyson S. Adapting the Ombudsman Idea to the 21st Century: Fighting Puffery, E-Government, and Forensic Investigations..University of New Brunswick (Saint Johncampus) URL: https://www.cpsa-acsp.ca/papers-2008/Hyson.pdf. 
study, P. Norris notes that «cyber-optimists hope that the development of the interactive services is a new channel of communication, and that improving the efficiency of digital technologies will help to increase the effectiveness of representative democracy and to establish a relationship between the citizen and the state. In contrast, cyber-pessimists question the ability of governments to adapt to the new environment ${ }^{26}$.

In the national legal sphere, the process of borrowing of the institute of ombudsman began with the adoption of the Constitution of Ukraine (1996) in the form of the classic model of the Parliamentary Ombudsman. In 1997, the Parliament of Ukraine adopted the Law of Ukraine «On the Ukrainian Parliament Commissioner for Human Rights», according to which the Commissioner exercises parliamentary control over the observance of the constitutional rights and freedoms of man and citizen and protection of the rights of everyone in the territory of Ukraine ${ }^{27}$. For that, the Commissioner carries out his or her activities independently of other state bodies and officials and, despite the parliamentary way of formation, his or her powers cannot be terminated or limited in the event of expiration of term of the authority of the Verkhovna Rada of Ukraine or its dissolution (self-dissolution).

In the legal literature, researchers point out that the modern period is characterized by the permanent development of the institutional specialization of ombudsmen and the fulfilment of the functions of ensuring the realization of human rights in various spheres of public relations (public administration, military, penitentiary system, taxes and business, medicine) and various most vulnerable categories of the population (children, persons with disabilities, war veterans, national minorities, migrants, LGBTI community, patients, etc.), the spread of the functions for control and surveillance of the carried out by the regional and municipal authorities and so on ${ }^{28}$.

Recently, a number of institutions have been established in Ukraine according to the initiative both of the President and the government. They are intended to promote the exercise of the powers of the relevant bodies in the field of respect for the rights and legitimate interests of the certain categories of persons. These institutions include the Commissioner of the

${ }^{26}$ Norris P. Digital Divide: Civic Engagement, Information Poverty, and the Internet Worldwide. NewYork: Cambridge University Press, 2001. P. 112.

${ }^{27}$ Про Уповноваженого Верховної Ради України з прав людини: Закон України від 23.12.1997 p. URL:http://zakon2.rada.gov.ua/laws/show/776/97-вр.

${ }^{28}$ Контроль за діяльністю органів публічної влади: національний досвід та міжнародні стандарти: аналітична доповідь / Ю. С. Шемшученко (керівник кол. авт.), О. В. Скрипнюк, Н. Р. Малишева та ін. Київ: Вид-во «Юридична думка», 2018. С. 74-83 
President of Ukraine for Children»s Rights (2011), the Commissioner for the Rights of the Crimean Tatar People (2014), the Commissioner for Rehabilitation of the Participants in Anti-Terrorist Operation Who Received Injuries, contusion, mutilation or Other Illnesses While Participating in Anti-Terrorist Operation (2016).

Accordingly, the Government has instituted such official bodies as the Government Ombudsman for Gender Policy (2017) and the Business Ombudsman (2014). At the same time, there are separate institutions designed to ensure that the rights of the persons with disabilities are respected, both under the President of Ukraine and under the Cabinet of Ministers of Ukraine (namely the Presidential Commissioner for the Rights of Persons with Disabilities (2014) and the Government Commissioner for the Rights of the Persons with Disabilities (2017).

It is worth noting that the introduction and existence of these institutions cannot be attributed to the classic model of the Ombudsman, since they are appointed, fully controlled by the relevant governmental authority (President or Government). That is, such a model for the existence of a system of human rights ombudsmen is likely to be «quasiombudsman».

In the process of finding the optimal model of the Ombudsman, according to the initiative of the President of Ukraine, on 29.08.2019, a bill was submitted to the Verkhovna Rada of Ukraine to amend Articles 85 and 101 of the Constitution of Ukraine (concerning the authorized representatives of the Verkhovna Rada of Ukraine) ${ }^{29}$, according to which it was proposed to change the nature and content of the functional orientation of the activities carried out by Commissioners of the Verkhovna Rada of Ukraine, at the same time expanding the powers of the Parliament regarding their appointment and dismissal.

The need to amend the Constitution of Ukraine, as stated in the explanatory note to the bill, is to «create an effective and efficient parliamentary control mechanism for respect for human and citizen rights and freedoms in Ukraine. It is obvious that one official - the Commissioner of the Verkhovna Rada of Ukraine for Human Rights, who is currently assigned to this function, cannot effectively fulfil his or her duties» ${ }^{30}$.

\footnotetext{
${ }^{29}$ Проект Закону про внесення змін до статей 85 та 101 Конституції України (щодо уповноважених Верховної Ради України) URL: https://w1.c1.rada.gov.ua/pls/zweb2/ webproc4_1?pf3511=66256.

${ }^{30}$ Пояснювальна записка до проекту Закону України «Про внесення змін до статей 85 та 101 Конституції України (щодо уповноважених Верховної Ради України)». URL: https://w1.c1.rada.gov.ua/pls/zweb2/webproc4_1?pf3511=66256.
} 
Of course, the project initiative to improve the functioning of the Parliamentary Ombudsman»s model towards the introduction of functional specialization contains certain advantages and disadvantages. The main benefit is the optimization of the parliamentary oversight mechanism for human rights, and the disadvantage may be the threat of unlimited expansion of the network of specialized parliamentary ombudsmen.

Of course, at the doctrinal level, the issue of the reception of specialized ombudsmen such as the «municipal ombudsman» ${ }^{31}$, «the migration ombudsman» ${ }^{32}$, «the medical ombudsman» ${ }^{33}$ and others has been actively discussed recently. The experience of functioning of the abovementioned officials in foreign countries has allowed to optimize and increase the effectiveness of the whole mechanism of human rights protection.

In general, considering the above-mentioned ideas, it is only necessary to emphasize that during the reformation process in order to improve the effectiveness of the human rights protection mechanism, it is necessary to develop a unified concept of the establishment of the human rights protection system, clearly defining which specific institutions are being proposed, including the list of the ombudsmen and the only model within which they can carry out their functions.

In developing this concept, the experience of functioning of ombudsmen in foreign countries and the domestic practice of state building should be taken into account.

\section{Reception of the institute of mediation in Ukraine: finding the best model through the prism of foreign experience}

Mediation (mediation - intervention between conflicting parties to promote reconciliation, settlement, or compromise ${ }^{34}$ ) is one way of

${ }^{31}$ Батанов О.В. Муніципальний омбудсман як елемент локальної системи захисту прав людини: інституційні та функціональні аспекти. Часопис Київського університету права. 2016. № 1. С. 69.

32 Агєєв О.Д. Конституційно-правовий статус омбудсмана 3 питань міграції: зарубіжні моделі та перспективи запровадження в Україні: автореф. дисс. канд.. юрид. наук спец. 12.00.02. Харків, 2017. С. 4-5.

${ }^{33}$ Наулік Н.С. Інститут медичного омбудсмана в Україні: запровадження та перспективи розвитку. Матеріали II Всеукраїнської науково-практичної конференції «Медичне право України : правовий статус пацієнтів в Україні та його законодавче забезпечення (генезис, розвиток, проблеми і перспективи вдосконалення)». Львів: Львівський Обласний Благодійний Фонд . 2008. С. 211.

${ }^{34}$ Mediation. Merriam-Webster Dictionary. URL: https://www.merriam-webster.com/ dictionary/mediation. 
protecting human rights, which is used to mutually beneficial (consensually) resolve a conflict with the assistance of a third party (mediator).

In the historical aspect, the roots of the Mediation Institute can be found in Phoenician civilization and ancient Babylon. This institute has become widespread in China and Japan. In these countries, up to modern time, the reconciliation of the parties through dialogue is more effective than appealing to the public authorities. The further development of the mediation institute took place in Greece, where mediators were known as «proxenetas», and then in ancient Rome. A legislative regulation of the status of mediators appeared in ancient Rome, starting with Justinian»s Digest (Pandects). In Roman law, they were called differently: «intersunus», «medium», «intersessor», «chilantrorus», «interrorlator», «sonsiliator», «intrrillosut», «interrèsr», and at last mediators ${ }^{35}$.

In the process of developing social relations and finding alternative forms of dispute resolution, the restoration (revival) of the institute of mediation takes place initially in the countries of the Anglo-Saxon system of law in the second half of the twentieth century (USA, UK and Austria). In particular, in 1947, the United States created the Federal Mediation and Conciliation Service (Federal Mediation Conciliation Service) as an independent agency of the US Government. This body is tasked with preventing or minimizing the impact of free-trade labour disputes through mediation, reconciliation and voluntary arbitration ${ }^{36}$. This body functions up to this day and mainly facilitates labor disputes.

In the modern sense, mediation emerged in the United States in the early 1970s. Initially, these were pilot projects on the use of the mediation procedure, but the successful use of mediation was the impetus for the regulatory design of this institute in 2001 into the Uniform Mediation Act (Uniform Mediation Act) ${ }^{37}$.

The reception of the institute of mediation in Europe takes place in the late twentieth and early twenty-first centuries. In particular, the Council of Europe accepts a number of recommendations: Recommendation Rec (98) 1 on mediation in family matters ${ }^{38}$, Recommendation Rec (99) 19 on

35 Ткаченко В.Б., Манухина О.А. Медиация как современный способ решения конфликта.Недвижимость: экономика, управление. 2015. № 1. С. 87.

${ }_{36}$ Federal Mediation and Conciliation Service: official site.URL:https://www.fmcs.gov/ aboutus/our-history/

${ }^{37}$ Uniform Mediation Act (2001). JournalofDisputeResolution. 2003. № 1. P. 14-20.

38 Рекомендация № R (98) 1 Комитета министров государствам-членам касательно медиации в семейных вопросах от 02.01.1998 г. URL: http://www.commonground.org.ua/ lib_law.shtml. 
mediation in criminal matters ${ }^{39}$, Recommendation Rec (2001) 9 on alternative dispute resolution between administrative authorities and private parties ${ }^{40}$, Recommendation Rec (2002) 10 on mediation in civil matters $^{41}$. In 2004, the European Code of Conduct for Mediators was adopted $^{42}$.

In addition, Directive 2008/52 / EC of the European Parliament and of the Council on certain aspects of mediation in civil and commercial matters was adopted in order to better implement the institution of mediation within the framework of European Union legislation ${ }^{43}$.

In the countries of the post-socialist space, the process of the reception of the institute of mediation, which has already received proper legal formulation by adopting a special law (Republic of Kazakhstan (2011), Russian Federation (2010), Georgia (2010), Belarus (2014), etc.), is also gradually taking place.

It is worth emphasizing that in the process of reception of the Institute of Mediation in foreign countries, various models and types of it were formed. And this is quite logical, since the idea borrowed from the donor country (concept, doctrine, institute, etc.) in the process of perception by the recipient country can take on specific forms, features and qualitatively updated interpretation. A number of social, economic, political, organizational, cultural and other factors facilitates this.

Referring to the auestion above, the main models and types of mediation produced during the practical use of foreign countries are highlighted. Thus, I.G. Yasynovskyi, analysing models of mediation in the foreign countries, proposes to specify: 1) judicial mediation (Canada, Germany); 2) lawyer mediation (Italy); 3) notarial mediation (Georgia); 4) professional mediation (USA) ${ }^{44}$.

${ }^{39}$ Рекомендація N R (99) 19 Комітету міністрів Ради Свропи державам - членам Ради, які зацікавлені в організації медіації у кримінальних справах від 15.09.1999 p. URL: http://zakon3.rada.gov.ua/laws/show/994_828.

${ }^{40}$ Рекомендация Rec (2001) 9 Комитета министров государствам-членам об альтернативах судебному разбирательству между административными органами и частными сторонами от 5 сентября 2001 года URL: http://www.csr.ru/document/original_648.stm.

${ }^{41}$ Рекомендация Rec (2002) 10 Комитета Министровгосударствам-членам по медиации в граждански хделах от 18.09.2002 г. URL: http://www.commonground.org.ua/lib_law.shtml.

42 European Code of Conduct for Mediators (2004) URL:http://ec.europa.eu/civiljustice/ adr/adr_ec_code_conduct_en.pdf.

${ }^{43}$ Directive 2008/52/EC of the European Parliament and of the Councilof 21 May 2008 oncertain aspects of mediationin civil and commercial matters.Official Journal of the European Union. № L 136. P. 3-8.

${ }^{44}$ Ясиновський І.Г. Характеристика моделей медіації в розвинутих країнах. Юридичний вісник. 2014. № 4 (33). С. 95. 
Another scientist N.V. Fedorenko identifies the following types of mediation in the international practice: 1) conciliation procedures combined with the state procedure (Great Britain, USA, Japan, Croatia, Greece and Belarus); 2) public mediation (Russia); 3) mediation based on the Harvard method and principle (Hungary, Portugal and Russia; 4) competitive mediation (USA); 5) consolidation (Russia, Switzerland and France); 6) private mediation (USA, UK, Russia and Germany); 7) integrated mediation (Germany) ${ }^{45}$.

Therefore, from the above it becomes clear that in some countries different models and types of mediation exist at the same time. Thus, recognizing the expediency and necessity of the reception of the institute of mediation as an alternative way of resolving legal disputes and an innovative way of protecting constitutional human rights in Ukraine, it is necessary to decide the following. Should the institute of mediation take the form of an extra-judicial protection of human rights, whether it would be a binding part of the justice system, or would it be applied at all stages of the dispute. Also the status of mediators as a person who will directly mediate in the process of conflict resolution, the categories of disputes that can be resolved with the involvement of a mediator, the voluntariness or obligation of mediation, etc. - are relevant at this stage ${ }^{46}$.

For many years, the institute of mediation has actually been operating in Ukraine. However, as the representatives of the Ukrainian Academy of Mediators quite rightly point out, «to this day, Ukrainian mediators work without legal support for their activity, masterfully using the limited possibilities of using mediation within the current legislation» ${ }^{47}$. Recently the NGOs actively investigate foreign experience of mediation and take over the functions of training mediators (NGO "National Association of Mediators of Ukraine” ${ }^{48}$, NGA “Ukrainian Academy of Mediation”, etc.). training of mediators (Odessa Regional Mediation Group (Odessa), Podilsky Mediation Center (Vinnytsia), Ukrainian Mediation Center at

\footnotetext{
${ }^{45}$ Федоренко Н.В. Медиация в России: понятие, характерные особенности. Наука и образование: хозяйство и экономика; предпринимательство; право и управление. 2016. № 3 (70). C. 50-51.

${ }^{46}$ Верлос Н.В. Рецепція інституту медіації як альтернативного способу захисту конституційних прав людини і громадянина в Україні. Вісник Запорізького національного університету: Збірник наукових пращьь. Юридичні науки. 2018. № 1. С. 32.

${ }^{47}$ Крестовська Н., Романадзе Л., Барабаш Т. Медіація в Україні: нюанси законодавчого врегулювання: публікація представників Української академії медіації URL: http://mediation.ua/wp-content/uploads/2017/03/stattya-Mediatsiya-v-Ukrayini-nyuansizakonodavchogo-vregulyuvannya.pdf.

${ }^{48}$ Національна асоціація медіаторів України URL: http://namu.com.ua/ua/info/ mediation/where-to-study.
} 
KMBS (Kyiv), Mediation School of the Academy of Advocacy of Ukraine (Kyiv), etc.).

From the above it can be concluded that today the process of the reception of the institute of mediation in Ukraine has beem intensified, but since this process involves not only borrowing but also perception (implementation) of this institute, it is necessary to establish the necessary legal conditions for its functioning in order to integrate this institute more effectively to the legal system of Ukraine.

The normative basis that provides a real opportunity for the functioning of the institute of mediation is the norm specified by Part 6, Article 55 of the Constitution of Ukraine according to which "everyone has the right in any unlawful way to protect his or her rights and freedoms from violations and unlawful encroachments" ${ }^{9}$. Analyzing the normative content of the abovementioned constitutional prescription, one can speak about the possibility of a person to defend his or her constitutional rights, including through the institute of mediation, of course, if the legislation of Ukraine is not violated in the process of mediation.

In national law, the term «mediation» begins to be used since the adoption of the Law of Ukraine "On Free Legal Aid» (2011). Thus, according to Clause 4 of Part 2 of Article 7 of the abovementioned law, services of free primary legal aid in particular include "providing assistance in ensuring access of a person to secondary legal assistance and mediation" 50 . The Strategy for reforming of the judiciary, the system of justice, and ancillary legal institutions for 2015-2020, approved by the Decree of the President of Ukraine of May 20, 2015, also emphasizes the need to "... expand ways of alternative (extrajudicial) settlement of disputes, in particular, through the practical implementation of the institute of mediation and arbitration" ${ }^{51}$.

Today, the normative definition of the term «mediation» is only enshrined in the State Standard for Social Mediation Services (17.08.2016), namely «mediation is defined as a method of resolving conflicts / disputes by which two or more parties to the conflict / dispute

\footnotetext{
${ }^{49}$ Конституція України від 28 червня 1996 р. (зі змінами) URL: http://zakon5.rada.gov.ua/ laws/show/254к/96-вр.

50 Про безоплатну правову допомогу: Закон України від 02.06.2011 p. URL: http://zakon3.rada.gov.ua/laws/show/3460-17?nreg=3460-

$17 \&$ find $=1 \&$ text $=\% \mathrm{EC} \% \mathrm{E} 5 \% \mathrm{E} 4 \% \mathrm{~B} \% \mathrm{E} 0 \& \mathrm{x}=7 \& \mathrm{y}=6 \# \mathrm{w} 11$.

${ }^{51}$ Стратегія реформування судоустрою, судочинства та суміжних правових інститутів на 2015-2020 роки, затверджена Указом Президента України від 20 травня 2015 року URL: http://zakon3.rada.gov.ua/laws/show/276/2015?nreg=276\%2F2015\&find=1\&text=\%E0\% EB\%FC\%F2\%E5\%F0\%ED\%E0\%F2\%E8\%E2\%ED\%E5\&x=7\&y=5.
} 
are trying to reach an agreement in a structured process involving the conciliator/mediator to resolve it» ${ }^{52}$. In addition, since September 8, 2016, mediation has been included in the list of paid social services ${ }^{53}$. At the same time, mediation covers assistance in conflict resolution, negotiation; working out ways and terms of the conflict resolution ${ }^{54}$.

That is, the evidence indicates an attempt at a subordinate level to regulate this institute under the consideration, whereby mediation is offered to be defined solely as a social service, and therefore its recipient can be only a person or a family, including a foster home, family-type orphanage, legal guardianship and trusteeship, a separate social group, including ethnicity, health status, who are under the influence of difficult circumstances and who require the provision of social services or receive such services ${ }^{55}$. Such an interpretation of mediation significantly narrows its content and significantly limits the range of persons who can use this method to resolve a dispute.

In addition, at the end of 2017, the profession of mediator, namely «specialist in conflict resolution and mediation in the socio-political sphere» is included in the Classifier of the Professions of Ukraine DK 003: $2010^{56}$. Although without the regulatory definition of educational and qualification requirements for the profession «mediator» to include it in the Classifier of the Professions is premature. The analysed legal framework of functioning of the institute of mediation in Ukraine testifies to the subordinate nature of the legal regulation of this institute and to the urgent need for the adoption of a special law on mediation.

Summarizing, it is worth noting that since the reception of mediation is a complex, multidimensional process that involves not only borrowing, but also taking into account the legal system of this institute, more steps must

${ }^{52}$ Про затвердження Державного стандарту соціальної послуги посередництва (медіації): Затверджено Наказом Міністерства соціальної політики від 17.08.2016 № 892 URL: http://zakon2.rada.gov.ua/laws/show/z1243-16.

${ }^{53}$ Про внесення змін до переліку платних соціальних послуг: Постанова Кабінету Міністрів України від 08.09.2016 № 596 URL: http://zakon5.rada.gov.ua/laws/show/596-2016п/paran5\#n5.

${ }^{54}$ Про затвердження Переліку соціальних послуг, що надаються особам, які перебувають у складних життєвих обставинах і не можуть самостійно їх подолати: Наказ Міністерства соціальної політики України від 03.09.2012 p. № 537 URL: http://zakon3.rada.gov.ua/ laws/show/z1614-12.

${ }^{55}$ Про затвердження Державного стандарту соціальної послуги посередництва (медіації): Затверджено Наказом Міністерства соціальної політики від 17.08.2016 № 892 URL: http://zakon2.rada.gov.ua/laws/show/z1243-16.

${ }^{56}$ Зміна № 6 до Класифікатора Професій ДК 003:2010: Затверджена Наказом Міністерства економічного розвитку і торгівлі України від 26.10.2017 р. № 1542 URL: http://www.msp.gov.ua/files/zmina6.pdf. 
be taken to complete it. Therefore, the reception of the institute of mediation as an alternative way of protecting constitutional human and citizen rights in Ukraine is a promising area of reform with a focus on the decentralization of the judiciary, a quality upgrade of the justice system, and a substantial discharge of the courts. However, the reception of the institute of mediation should take into account factors that will facilitate effective integration and take into account the potential threats that may arise during this process.

\section{CONCLUSIONS}

Summarizing the abovementioned, it can be stated that during the process of balanced functioning and development of the Ukrainian statehood, first of all, it is necessary to carry out a systematic constitutional and legal modernization in accordance with a certain foreign policy vector, which also requires a number of changes in the institutional design of the constitutional mechanism of public power. In many ways, this process is accompanied by the reception of certain ideas, concepts, doctrines, institutions and norms in the constitutional law of Ukraine. The reception of the proper institutes of the constitutional mechanism for the protection of human rights, such as the institute of ombudsman and the institute of mediation, deserves special attention.

Today, the combined model of the institute of ombudsman is functioning in Ukraine. On the one hand, the parliamentary model continues to develop, and on the other, an extensive network of «quasiombudsman» institutions begins to operate. That is why during the process of constitutional and legal modernization, while developing a mechanism for the protection of human rights the development of an optimal model of alternative (extrajudicial) human rights institutions should be paid more, including the ombudsmen who would be able to function effectively and facilitate the implementation of the human rights protection mechanism.

In the course of reception of a new institute of mediation for our country it is necessary to carefully consider its implementation in the Ukrainian constitutional and legal reality. Firstly, it means the necessity to consider the type of mediation model. Secondly, it is necessary to take into account the state of the sectoral legislation. Thirdly - gradually forming the public consciousness towards the perception of the new institute for the protection of constitutional human rights, and fourthly, taking into account the peculiarities of the Ukrainian mentality, contribute to building a credit of the civil society's confidence for the new democratic institution. Fifthly, it is necessary to consider human resources obtained by the professional 
mediators and to form a system of institutions that is able to prepare them and take into account other factors that can affect the reception process of the institute of mediation in Ukraine.

Therefore, the reception of the ombudsman and mediation institutions plays an important role in the process of enhancing the effectiveness of the constitutional mechanism for the protection of human rights in Ukraine, and it will also facilitate the implementation of the official course of European integration enshrined in the Constitution of Ukraine. It should be remembered that reception in the constitutional law is a complex multistage process that must be approached cautiously and carefully in order to prevent constitutional and legal distortions.

\section{SUMMARY}

The study has tried to comprehensively analyse the reception of the proper institutes of the constitutional mechanism of human rights protection in Ukraine based on the comparative legal analysis of the foreign experience and positive achievements of the functioning of ombudsman institutions and mediation in the advanced democracies.

An analysis of the overseas practice of the institution of ombudsman confirms that this democratic institution is functioning effectively in most democratic countries. In Ukraine, the reception of the constitutional and legal institute under study is incomplete it is characterized by the search for an optimal model. This process is also facilitated by a project initiative to make amendments to the Constitution of Ukraine.

Unlike the institution of ombudsman, the reception of the institute of mediation is a more complex and multifaceted process, as it is not only about borrowing, but also about the reception of this institute that is new to the Ukrainian legal system. Therefore, the reception of the institute of mediation as an alternative way of protecting constitutional human and citizen rights in Ukraine is a promising direction for the development of state building.

Based on the analysis, the author concludes that the reception of the institute of ombudsman and the institute of mediation plays an important role in the constitutional mechanism of human rights protection in Ukraine in order to increase the effectiveness of their implementation and protection. 


\section{REFERENCES}

1. Про ратифікацію Угоди про асоціацію між Україною, з однієї сторони, та Європейським Союзом, Європейським співтовариством з атомної енергії і їхніми державами-членами, з іншої сторони: Закон України від 16 вересня 2014 p. URL: http://zakon2.rada.gov.ua/ laws/show/1678-18.

2. Про Заяву Верховної Ради України «Про європейський вибір України»: Постанова Верховної ради України від 16.09.2014 р. URL: http://zakon5.rada.gov.ua/laws/show/ru/1679-18.

3. Про внесення змін до Конституції України (щодо стратегічного курсу держави на набуття повноправного членства України в Європейському Союзі та в Організації Північноатлантичного договору: Закон України від 07.02.2019 p. URL: https://zakon.rada.gov.ua/ laws/show/2680-19\#n6.

4. Howard Ch.L. The Organizational Ombudsman: origins, roles and operations: a legal guide, Chicago: American Bar Association, 2010. 642 p.

5. The World Book Encyclopedia. Field Enterprise as Educational Corporation / Holbert N. Corrol. N.Y., 1972. V. 14. P. 574.

6. Rowat D. C. The Ombudsman, Citizcnis Defender: Pref'ase to Second Edition. London: George Allen and Unwin, 1986. S. XXIV.

7. Шляхтун П.П. Парламентаризм: словник-довідник. К.: Парламентське вид-во, 2003. 151 с.

8. Барчук В.Б. Уповноважений Верховної Ради України з прав людини як суб'єкт забезпечення національної безпеки : автореферат дисертації ... кандидата юридичних наук. 12.00.02 - конституційне право; муніципальне право. К., 2006. 21с.

9. Закоморна К.О. Інститут омбудсмана як засіб забезпечення прав і свобод людини та громадянина (порівняльно-правовий аналіз): автореферат дисертації ... кандидата юридичних наук: 12.00.02 конституційне право; муніципальне право. Харків., 2000. 19 с.

10. Хаманева Н. Ю. Место и роль института омбудсмена в системе правового контроля. Правоведение. 1992. № 2. С. 84-88.

11.Марцеляк О.В. Конституційно-правовий статус інституту омбудсмана: світовий досвід та Українська модель. Автореферат дисертації ... доктора юридичних наук 12.00 .02 - конституційне право. Харків, Одеса, 2004. 18 с.

12.Голяк Л.В. Інститут спеціалізованого омбудсмана: світовий досвід організації та діяльності: дисертація на здобуття наукового ступеня кандидата юридичних наук. спец. 12.00.02 конституційне право; муніципальне право. К., 2009. 228 с. 
13.Верлос Н.В. Омбудсман в механізмі захисту прав людини в Україні: пошук ефективної моделі в контексті запозичення зарубіжного досвіду. Вісник Запорізького начіонального університету: Збірник наукових працьь. Юридичні науки. 2018. № 2. С. 23-32.

14. Cheng, Hing Yong. The Emergence and Spread of the Ombudsman Institution. Annals of the American Academy of Political and Social Science. 1968. Vol. 377. May. P. 20-30.

15. Rowat D. The Ombudsman Plan: The Worldwide Spread of an Idea. Rev. 2nd ed. Lanham: University Press of America, 1985. 199 p.

16.Seneviratne M. Ombudsmen 2000 URL: www.bioa.org.uk/ BIOANew/Ombudsmen-2000-Mary\%20Seneviratne.pdf.

17. Мухитдинов Е.Н. Институт омбудсмена (уполномоченного по правам человека) в международном праве: история возникновения и развития в странах мира и Казахстана. баяндамалары=Докладь Наџиональной академии наук Республики Казахстан. 2008. № 6. С. 95-111.

18.Новикова А.Е. Институт Уполномоченного по правам человека в Российской Федерации (историко-правовой и теоретико-правовой аспекты): автореф. дисс. канд. юрид. наук: спец. 12.00.01; 12.00 .02 конституционное право; муниципальное право. СПб., 2007. 24 с.

19. Носырева Е. И. Особенности института омбудсмена в США. Право и политика. 2001. № 9. С. 12-15.

20. Спичак Ю.Г. Модели института омбудсмена на современном этапе. Государственное строительство и право. 2003. Вып. 4. C. 53-62.

21.Janzen Fred G. A historical study of the campus ombudsman In united states higher education: a dissertation. In education Submitted to the Graduate Faculty of Texas Tech University in Partial Fulfillment of the Requirements for the Degree of doctor of education, Texas 1971. $254 \mathrm{p}$.

22. Lubbers Jeffrey S. Ombudsman Offices in the Federal Government - An Emerging Trend? Administrative Law and Regulatory Practice. Spring 1998 Vol. 2. № 1. URL: https://www.americanbar.org/newsletter/ publications/gp_solo_magazine_home/gp_solo_magazine_index/lubbers. html.

23. Hyson S. Adapting the Ombudsman Idea to the 21st Century: Fighting Puffery, E-Government, and Forensic Investigations. University of New Brunswick (Saint John campus) URL: https://www.cpsa-acsp.ca/ papers-2008/Hyson.pdf. 
24. Norris P. Digital Divide: Civic Engagement, Information Poverty, and the Internet Worldwide. New York: Cambridge University Press, 2001. 303 p.

25.Про Уповноваженого Верховної Ради України з прав людини: Закон України від 23.12.1997 p. URL: http://zakon2.rada.gov.ua/laws/ show/776/97-вр.

26. Контроль за діяльністю органів публічної влади: національний досвід та міжнародні стандарти: аналітична доповідь / Ю.С. Шемшученко (керівник кол. авт.), О. В. Скрипнюк, Н. Р. Малишева та ін. Київ: Вид-во «Юридична думка», 2018. С. 74-83.

27.Проект Закону про внесення змін до статей 85 та 101 Конституції України (щодо уповноважених Верховної Ради України) URL: https://w1.c1.rada.gov.ua/pls/zweb2/webproc4_1?pf3511=66256.

28. Пояснювальна записка до проекту Закону України «Про внесення змін до статей 85 та 101 Конституції України (щодо уповноважених Верховної Ради України)» URL:https://w1.c1.rada.gov.ua/pls/ zweb2/webproc4_1?pf3511=66256.

29.Батанов О.В. Муніципальний омбудсман як елемент локальної системи захисту прав людини: інституційні та функціональні аспекти. Часопис Київького університету права. 2016. № 1. С. 65-69.

30.Агєєв О.Д. Конституційно-правовий статус омбудсмана з питань міграції: зарубіжні моделі та перспективи запровадження в Україні: автореф. дисс. ... канд.. юрид. наук спец. 12.00 .02 конституційне право; муніципальне право. Харків, 2017. 21 с.

31.Наулік Н.С. Інститут медичного омбудсмана в Україні: запровадження та перспективи розвитку. Матеріали II Всеукраїнської науково-практичної конференції «Медичне право України : правовий статус пацієнтів в Україні та його законодавче забезпечення (генезис, розвиток, проблеми і перспективи вдосконалення)». Львів: Львівський Обласний Благодійний Фонд. 2008. С. 210-212

32.Ткаченко В.Б., Манухина О.А. Медиация как современный способ решения конфликта. Недвижимость: экономика, управление. 2015. № 1. C. 86-89.

33. Federal Mediation and Conciliation Service: official site. URL: https://www.fmcs.gov/aboutus/our-history.

34. Uniform Mediation Act (2001). Journal of Dispute Resolution. 2003. № 1. Р. 14-20.

35. Рекомендация № R (98) 1 Комитета министров государствамчленам касательно медиации в семейных вопросах от 02.01.1998 г. URL: http://www.commonground.org.ua/lib_law.shtml. 
36. Рекомендація N R (99) 19 Комітету міністрів Ради Європи державам - членам Ради, які зацікавлені в організації медіації у кримінальних справах від 15.09.1999 p. URL: http://zakon3.rada.gov.ua/ laws/show/994_828.

37. Рекомендация Rec (2001) 9 Комитета министров государствамчленам об альтернативах судебному разбирательству между административными органами и частными сторонами от 5 сентября 2001 года. URL: http://www.csr.ru/document/original_648.stm.

38. Рекомендация Rec (2002) 10 Комитета Министров государствам-членам по медиации в гражданских делах от 18.09.2002 г. URL: http://www.commonground.org.ua/lib_law.shtml.

39. European Code of Conduct for Mediators (2004) URL: http://ec.europa.eu/civiljustice/adr/adr_ec_code_conduct_en.pdf.

40. Directive 2008/52/EC of the European Parliament and of the Council of 21 May 2008 on certain aspects of mediation in civil and commercial matters. Official Journal of the European Union. № L 136. P. 3-8.

41.Ясиновський І.Г. Характеристика моделей медіації в розвинутих країнах. Юридичний вісник. 2014. № 4 (33). С. 94-98.

42. Федоренко Н.В. Медиация в России: понятие, характерные особенности. Наука и образование: хозяйство и экономика; предпринимательство; право и управление. 2016. № 3 (70). С. 49-54.

43.Верлос Н.В. Рецепція інституту медіації як альтернативного способу захисту конституційних прав людини і громадянина в Україні. Вісник Запорізького національного університету: Збірник наукових праць. Юридичні науки. 2018. № 1. С. 29-39. С. 32.

44.Крестовська Н., Романадзе Л., Барабаш Т. Медіація в Україні: нюанси законодавчого врегулювання: публікація представників Української академії медіації URL: http://mediation.ua/wpcontent/uploads/2017/03/stattya-Mediatsiya-v-Ukrayini-nyuansizakonodavchogo-vregulyuvannya.pdf.

45.Національна асоціація медіаторів України URL: http://namu.com.ua/ua/info/mediation/where-to-study.

46. Конституція України від 28 червня 1996 р. (зі змінами) URL: http://zakon5.rada.gov.ua/laws/show/254к/96-вр.

47.Про безоплатну правову допомогу: Закон України від 02.06.2011 p. URL: http://zakon3.rada.gov.ua/laws/show/3460-17?nreg= 3460-17\&find=1\&text=\%EC\%E5\%E4\%B3\%E0\&x=7\&y=6\#w11.

48. Стратегія реформування судоустрою, судочинства та суміжних правових інститутів на 2015-2020 роки, затверджена Указом Президента України від 20 травня 2015 року URL: 
http://zakon3.rada.gov.ua/laws/show/276/2015?nreg=276\%2F2015\& find $=1 \&$ text=\%E0\%EB\%FC\%F2\%E5\%F0\%ED\%E0\%F2\%E8\%E2\% $\mathrm{ED} \% \mathrm{E} 5 \& \mathrm{x}=7 \& \mathrm{y}=5$.

49.Про затвердження Державного стандарту соціальної послуги посередництва (медіації): Затверджено Наказом Міністерства соціальної політики від 17.08.2016 № 892 URL: http://zakon2.rada. gov.ua/laws/show/z1243-16.

50.Про внесення змін до переліку платних соціальних послуг: Постанова Кабінету Міністрів України від 08.09.2016 № 596. URL: http://zakon5.rada.gov.ua/laws/show/596-2016-п/paran5\#n5.

51.Про затвердження Переліку соціальних послуг, що надаються особам, які перебувають у складних життєвих обставинах і не можуть самостійно їх подолати: Наказ Міністерства соціальної політики України від 03.09.2012 p. № 537. URL: http://zakon3.rada.gov.ua/ laws/show/z1614-12

52. Про затвердження Державного стандарту соціальної послуги посередництва (медіації): Затверджено Наказом Міністерства соціальної політики від 17.08.2016 № 892. URL: http://zakon2.rada.gov.ua/ laws/show/z1243-16.

53.Зміна № 6 до Класифікатора Професій ДК 003:2010: Затверджена Наказом Міністерства економічного розвитку і торгівлі України від 26.10.2017 p. № 1542. URL: http://www.msp.gov.ua/ files/zmina6.pdf.

\section{Information about the author:} Verlos N. V.,

$\mathrm{PhD}$ in Law, Associate Professor, Department of Constitutional and Labor Law, Zaporizhzhya National University 66, Zhukovsky str., Zaporizhzhia, 69600, Ukraine 